\title{
OBSERVATIONS ON THE DEVELOPMENT OF THE HIGH BLOOD SEDIMENTATION RATE IN RHEUMATIC CARDITIS ${ }^{1}$
}

\author{
By ALVIN F. COBURN AND E. M. KAPP \\ (From the Department of Medicine, College of Physicians and Surgeons, Columbia University, \\ and the Presbyterian Hospital, New York City)
}

(Received for publication June 18, 1936)

The practical value of serial determinations of the erythrocyte sedimentation rate as an aid in detecting the presence of rheumatic activity has proved itself thoroughly among clinicians. Our findings during the last five years have been in complete accord with those of a number of other investigators ( 1 to 11 , inclusive). The erythrocyte sedimentation rate is regularly elevated in patients with rheumatic carditis, and even minor fluctuations seem to be directly related to the clinical course of the disease. Except when associated with congestive heart failure, a decreasing sedimentation rate nearly always reflects diminishing activity of the rheumatic process. The present paper deals with the initial development of a rise in sedimentation rate at the onset of the rheumatic attack, and with an investigation of the factors in blood directly responsible for the change.

The erythrocyte sedimentation rate in pharyngitis, scarlet fever and rheumatism

As shown in a previous publication (12), an attack of acute rheumatism is usually preceded by an upper respiratory infection with hemolytic streptococcus, which we designate as Phase I of

1 The work reported in this communication was carried out under The W. K. Kellogg Foundation Fund. the rheumatic attack. Following recovery from the primary infection, there is a symptom-free interval of from one to three (rarely five) weeks in length, during which the patient appears to be in perfect health. This we designate as Phase II. The rheumatic attack proper is referred to as Phase III. It has been possible in a number of known rheumatic subjects who have been under close observation for a period of years to follow the sedimentation rate from the onset of hemolytic streptococcus pharyngitis through Phase II into Phase III or complete recovery as the case might be. Many of these patients developed typical acute rheumatism. Some escaped all signs of rheumatic recrudescence. The sedimentation curves were quite different, depending on whether the patient developed a rheumatic attack or not. Sample curves of both types are presented in Figures 1 and 2.

It will be seen from these curves that the sedimentation rate was slightly or moderately elevated during pharyngitis in some of the individuals studied, and remained at a normal level in the others, irrespective of whether the infection was followed by rheumatism or not. In patients who escaped recrudescences (Figure 1) the sedimentation rate remained at its normal level or returned to normal in about two to three weeks

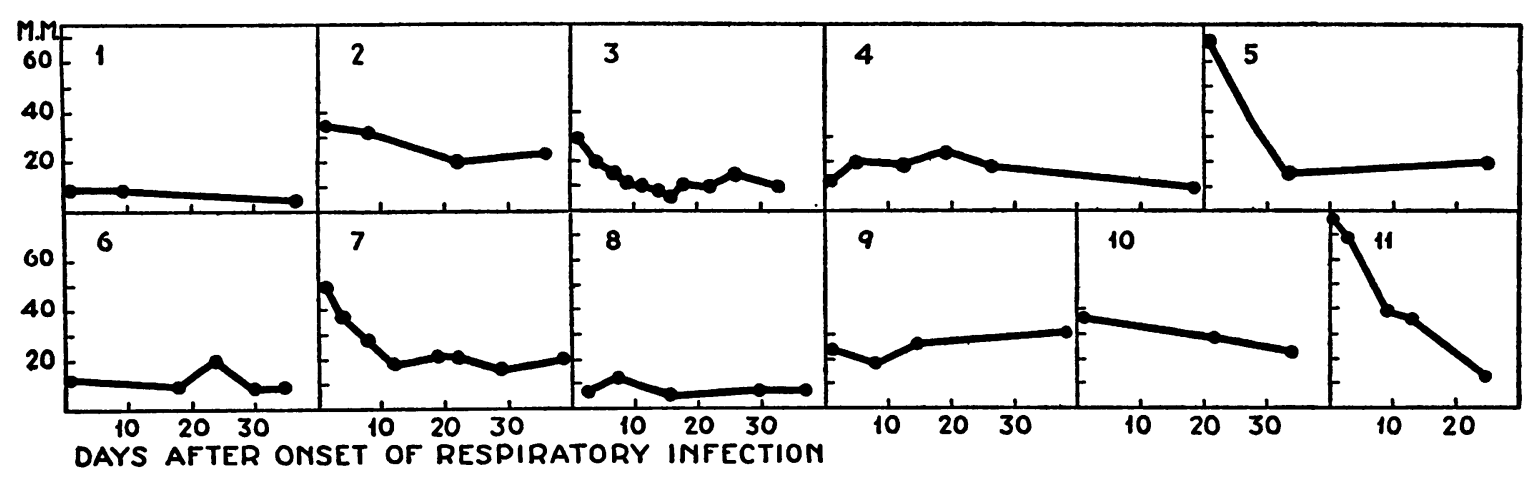

Fig. 1. Sedimentation Rates of Rheumatic Subjects with Hemolytic Streptococcus Pharyngitis Which Was Not Followed by Rheumatic Symptoms. 


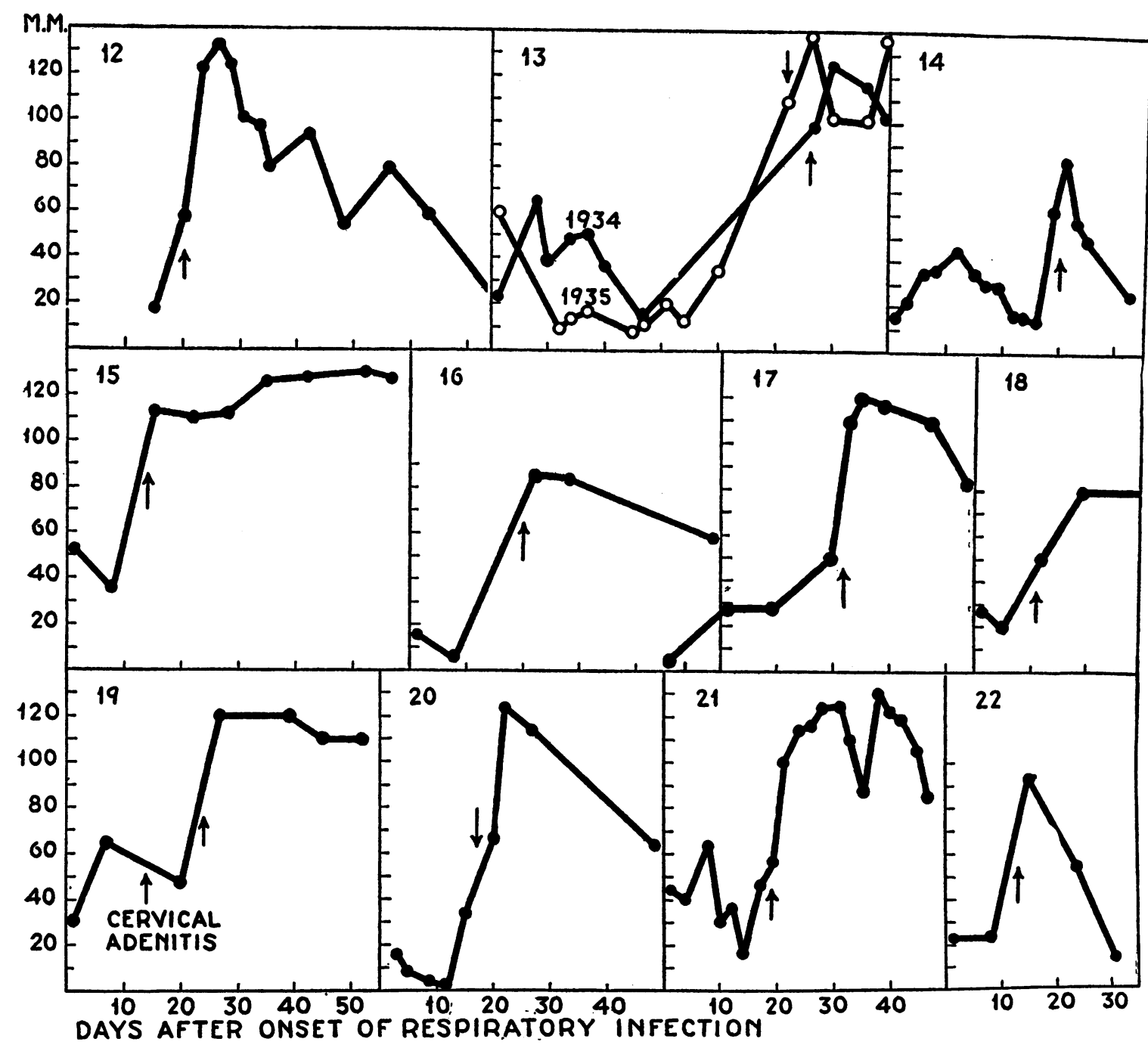

Fig. 2. Sedimentation Rates of Rheumatic Subjects with Hemolytic Streptococcus Pharyngitis Which Was Followed by Severe Rheumatic Carditis (Onset of Rheumatic Attack Indicated by Arrows).

from the onset of infection. In patients who developed rheumatic attacks, however (Figure 2), the subsidence of sedimentation rate after recovery from pharyngitis was interrupted by a second sharp increase coincident with or just preceding the onset of rheumatic symptoms.

A similar study was made of a control group of subjects with hemolytic streptococcus pharyngeal infections who had no history of previous rheumatic disease. This group consisted of $(a)$ 15 young adults, mostly nurses, with acute pharyngitis, whose throat flora contained hemolytic streptococcus in predominance, and (b) 10 patients, mostly children, admitted to Willard
Parker Hospital with typical scarlet fever. The sedimentation rate curves are presented in Figure 3.

Eighteen of these patients recovered without developing complications. Their sedimentation rate curves are indistinguishable from those shown in Figure 1. Five patients with pharyngitis and two with scarlet fever did develop complications during convalescence. All of these complications were accompanied by renewed increases in the sedimentation rate. These secondary increases were moderate, with the exception of one patient who developed, successively, otitis, mastoiditis, mild polyarthritis and electrocardio- 

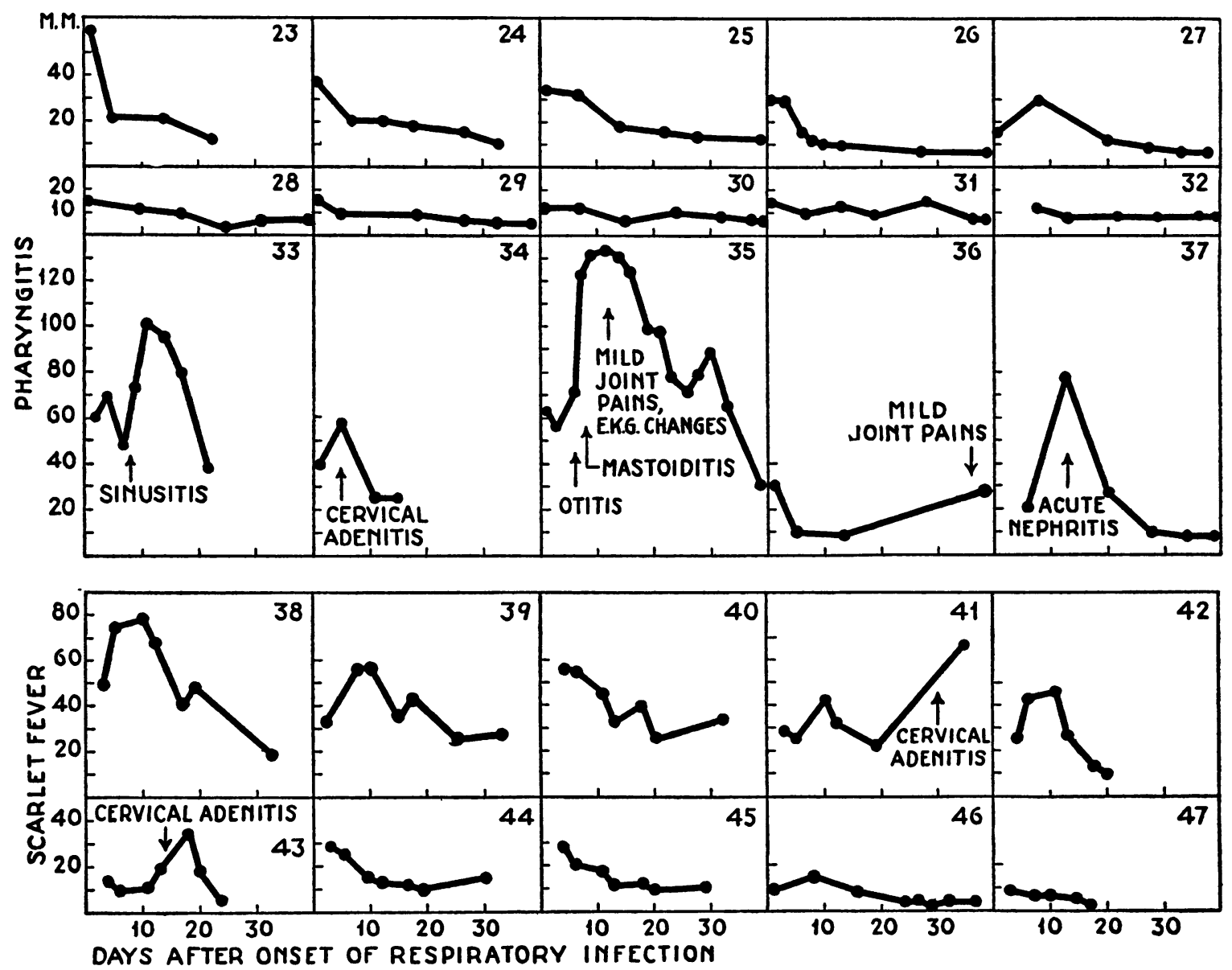

Fig. 3. Sedimentation Rates of Control Subjects with Hemolytic Streptococcus Respiratory Infections -Pharyngitis and Scarlet Fever.

graphic changes. In this case (Curve 35) the sedimentation rate rose to a level as high as that which usually accompanies rheumatic carditis (cf. Figure 2). Similar observations have been reported by Rhodin (13) who found a moderate increase in sedimentation rate during scarlet fever followed by a second larger increase in the event of complications, with a well marked minimum between them. The curves of several patients whose sedimentation rates were determined at frequent intervals showed cyclic fluctuations during the first week or two after infection similar to those observed by Rhodin (13) in scarlet fever. In our series of patients, this type of curve occurred not only during convalescence from scarlet fever (Patients 38, 39, 40, 41) but also during Phase II of acute rheumatism (Patients 13, 21). In summary, increases in sedimentation rate. may or may not occur during initial hemolytic streptococcus pharyngitis. It does occur during septic complications and during sequelae characterized by sterile inflammation.

Plasma proteins in relation to the erythrocyte sedimentation rate

The literature dealing with the factors in blood responsible for an increased sedimentation rate contains a wide variety of conclusions. However, the majority of investigators are agreed that the decisive factors reside in the plasma or serum rather than in the cells, and that abnormal sedimentation is accompanied by quantitative alterations in the protein fractions of plasma. Fåhraeus (14) pointed out that the amount of fibrinogen or serum globulin paralleled the sedimentation rate. This has been confirmed by Westergren et al. 
TABLE I

Serum protein values of nine patients with acute rheumatism, and of nine healthy control subjects

\begin{tabular}{|c|c|c|c|c|c|c|c|}
\hline \multicolumn{4}{|c|}{ Patients with acute rheumatism } & \multicolumn{4}{|c|}{ Controls } \\
\hline $\begin{array}{c}\text { Total } \\
\text { serum } \\
\text { protein }\end{array}$ & $\begin{array}{c}\text { Serum } \\
\text { albumin }\end{array}$ & $\begin{array}{c}\text { Serum } \\
\text { globulin }\end{array}$ & A/G ratio & $\begin{array}{l}\text { Total } \\
\text { serum } \\
\text { protein }\end{array}$ & $\underset{\text { albumin }}{\text { Serum }}$ & $\underset{\text { globum }}{\text { Serum }}$ & $A / G$ ratio \\
\hline $\begin{array}{c}\text { grams per } 100 \text { cc. } \\
6.8 \\
7.4 \\
7.0 \\
7.2 \\
8.1 \\
8.8 \\
8.0 \\
8.2 \\
7.9\end{array}$ & $\begin{array}{c}\text { grams per } 100 \mathrm{cc} \text {. } \\
3.9 \\
4.2 \\
4.5 \\
4.8 \\
4.7 \\
4.7 \\
4.1 \\
4.5 \\
4.5\end{array}$ & \begin{tabular}{|c|} 
grams per 100 cc. \\
2.9 \\
3.1 \\
2.5 \\
2.5 \\
3.4 \\
4.1 \\
3.9 \\
3.7 \\
3.4
\end{tabular} & $\begin{array}{l}1.34 \\
1.35 \\
1.82 \\
1.92 \\
1.40 \\
1.14 \\
1.05 \\
1.16 \\
1.32\end{array}$ & \begin{tabular}{|c|} 
grams per $100 \mathrm{cc}$. \\
6.7 \\
7.3 \\
6.9 \\
7.2 \\
7.2 \\
7.3 \\
7.0 \\
7.1 \\
7.3
\end{tabular} & \begin{tabular}{|c|} 
grams per $100 \mathrm{cc}$. \\
4.6 \\
4.8 \\
4.6 \\
4.9 \\
4.8 \\
4.9 \\
4.7 \\
5.2 \\
5.1
\end{tabular} & \begin{tabular}{|c|} 
grams per 100 cc. \\
2.1 \\
2.5 \\
2.3 \\
2.3 \\
2.4 \\
2.4 \\
2.3 \\
1.9 \\
2.2
\end{tabular} & $\begin{array}{l}2.19 \\
1.92 \\
2.00 \\
2.13 \\
2.00 \\
2.04 \\
2.04 \\
2.74 \\
2.32\end{array}$ \\
\hline $\begin{array}{c}\text { Average } \\
7.7\end{array}$ & 4.4 & 3.3 & 1.39 & 7.1 & 4.8 & 2.3 & 2.15 \\
\hline
\end{tabular}

(15) and by Bendien and Snapper (16) for a number of miscellaneous diseases. Gilligan and Ernstene (17) found a striking correlation between the quantity of plasma fibrinogen and the sedimentation rate in rheumatic fever. High levels of fibrinogen seem to be the rule in this disease, and we have also observed high levels of serum globulin in a series of nine patients with acute rheumatism accompanied by sedimentation rates of more than $100 \mathrm{~mm}$. in 1 hour (See Table I). However, the fact that high protein values accompany high sedimentation rates in no way proves a causal relationship.

In order to determine whether one of these factors was actually the cause of the high sedimentation rates in rheumatic fever, we attempted to reproduce the conditions necessary for rapid sedimentation by the modification of normal plasma (or serum) in various ways, including the addition of protein fractions isolated from the blood of normal individuals and patients with rheumatism. The sedimentation rates of washed human erythrocytes resuspended in modified plasma were then measured under standard conditions, in comparison with parallel measurements taken on red cells resuspended in the unmodified plasma of normal individuals and rheumatic patients.

The following technical precautions were observed throughout :

1. All the cells and sera used in any one experiment were of the same blood group.

2. Erythrocytes were washed three times with isotonic
$\mathrm{NaCl}$, kept in the refrigerator, and used only if less than 48 hours old.

3. Isotonicity was assured by dialyzing all protein fractions overnight against 0.85 per cent $\mathrm{NaCl}$.

4. Sodium citrate was used as anticoagulant.

5. Long glass tubes $(500 \mathrm{~mm}$.) were used for sedimentation, to minimize the effect of packing.

Protein fractions were prepared as follows. Fibrinogen was precipitated from whole citrated plasma by the addition of an equal volume of saturated $\mathrm{NaCl}$. This precipitate was dissolved in water and dialyzed, first against distilled water to remove excess salt, then against isotonic saline, and finally against isotonic saline under slight vacuum to reduce the volume to the desired level. The dialysis procedure was the same for all fractions.

Plasma globulin was precipitated from the supernatant fluid, after the removal of fibrinogen, by full saturation with $\mathrm{NaCl}$. The precipitate was dissolved in distilled water and dialyzed.

Serum globulin was precipitated from serum by saturation with $\mathrm{NaCl}$, dissolved in water and dialyzed. In rapidly sedimenting blood this fraction included a small amount of "residual" fibrinogen; i.e., a protein left in solution after clotting was complete, which could be precipitated by one-half saturated $\mathrm{NaCl}$.

Globulins were not subjected to further fractionation.

The albumin fraction included all protein left in the supernatant after full saturation with $\mathrm{NaCl}$. Dialysis was performed as usual.

Certain factors were found to play no significant part in the sedimentation mechanism. (1) Total serum lipoids: Serum defatted by Hartley's (18) method produced a sedimentation rate equal to that of untreated serum, in the case of both a slowly and a rapidly sedimenting blood. Similar observations have been recorded by Theorell (19) 
and by Ohlson and Rundquist (20). (2) Serum complement: Inactivation of serum by heating at $56^{\circ}$ for 30 minutes produced only slight changes in sedimentation rate.

Serum of rheumatic patient ............ $80 \mathrm{~mm}$. Inactivated serum of same patient ........ $75 \mathrm{~mm}$.

(3) Plasma crystalloids: Dialysis of whole plasma or whole serum did not affect the sedimentation rate provided that isotonicity was restored and that the concentration of total protein was not changed.

Certain factors which have been shown by previous workers to affect the sedimentation of erythrocytes were investigated in " reconstructed" bloods (plasma or serum plus washed cells), and were found to operate in the usual way. The sedimentation rate was slowed by increasing the ratio of red cells to plasma, and vice versa. Reduction of the total volume of normal plasma without increasing the salt concentration (by dialysis under negative pressure against isotonic saline), also diminished the sedimentation rate.

Whole plasma ...................... $45 \mathrm{~mm}$. Same, reduced to $4 \frac{5}{3}$ of original volume, iso-

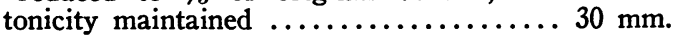

It was also found that dilution of plasma with isotonic salt (or Ringer's solution) resulted in a marked retardation of the sedimentation rate. Dilution of plasma to one-half or one-third of its original concentration resulted in a sedimentation rate approximately equal to that of the diluent alone. This is illustrated in Table II. The sedimentation rates are expressed as millimeters in 30 minutes.

The removal of fibrinogen from the plasma obtained from normal or rheumatic patients slowed sedimentation considerably; nevertheless, sera

TABLE II

The effect on the sedimentation rate of diluting plasma with physiological salt solutions

\begin{tabular}{|c|c|c|c|c|c|c|}
\hline $\begin{array}{l}\text { Plasma, } c c . \ldots \ldots \ldots \ldots \ldots \ldots \ldots \\
\text { Diluent, } c c . \ldots \ldots \ldots \ldots \ldots \ldots\end{array}$ & ${ }^{1.0}$ & $\begin{array}{l}.8 \\
.2\end{array}$ & $\begin{array}{l}.6 \\
.4\end{array}$ & .4 & $\begin{array}{l}.2 \\
.8\end{array}$ & $\begin{array}{l}0 \\
1.0\end{array}$ \\
\hline $\begin{array}{l}\mathrm{NaCl}, 0.85 \text { per cent } \ldots \ldots \ldots \ldots \\
\text { Ringer's solution } \ldots \ldots \ldots \ldots\end{array}$ & $\begin{array}{c}m m . \\
120\end{array}$ & $\begin{array}{r}m m . \\
95 \\
130\end{array}$ & $\begin{array}{c}m m . \\
60 \\
50\end{array}$ & $\begin{array}{r}m m . \\
3 \\
15\end{array}$ & $\begin{array}{c}m m . \\
\mathbf{0} \\
\mathbf{1 0}\end{array}$ & $\begin{array}{c}m m . \\
3 \\
2\end{array}$ \\
\hline $\mathrm{NaCl}, 0.85$ per cent. . ......... & 135 & 120 & 55 & 25 & 4 & 4 \\
\hline $\begin{array}{l}\mathrm{NaCl}, 0.85 \text { per cent } \ldots \ldots \ldots \ldots \\
\text { Ringer's solution } \ldots \ldots \ldots \ldots\end{array}$ & & $\begin{array}{l}70 \\
70\end{array}$ & $\begin{array}{l}25 \\
30\end{array}$ & $\begin{array}{l}8 \\
4\end{array}$ & 2 & $\begin{array}{l}6 \\
1\end{array}$ \\
\hline
\end{tabular}

from rheumatic patients showed evidence of a residual factor of some magnitude.

\begin{tabular}{|c|c|c|}
\hline & $\begin{array}{c}\text { Plasma } \\
\mathrm{mm} .\end{array}$ & $\begin{array}{c}\text { Serum } \\
\mathbf{m m} .\end{array}$ \\
\hline Rheumatic patient $(a)$ & . 110 & 85 \\
\hline Rheumatic patient $(b)$ & . . 120 & 45 \\
\hline Rheumatic patient (c) & $\ldots 100$ & 50 \\
\hline Normal individual $2(a)$ & $\ldots \ldots \ldots \ldots 10$ & 4 \\
\hline Normal individual $2(b)$ & & 20 \\
\hline
\end{tabular}

Albumin (i.e., serum from which the globulin had been removed) inhibited sedimentation almost completely.

Sample A

Plasma ...................... $135 \mathrm{~mm}$.

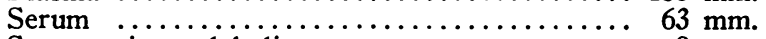

Serum minus globulin $\ldots \ldots \ldots \ldots \ldots \ldots \ldots \ldots \ldots, 8 \mathrm{~mm}$.

Sample B

Plasma ........................ $100 \mathrm{~mm}$. Plasma minus fibrinogen and globulin ....... $9 \mathrm{~mm}$.

It was not clear whether the disappearance of the sedimentation factor from serum on removal of globulin was due to the absence of globulin per se, or whether the inhibitory effect of dilution with saline was coming into play. This point was investigated further by incorporating fibrinogen or globulin fractions, or both, into equivalent quantities of normal plasma. As the final volume of the modified plasma was the same as that of the original normal plasma, the protein concentration of the modified plasma was higher than before. If the fractions used for modification had been inactive, their addition to normal plasma should have inhibited sedimentation, owing to the increase in the concentration of total protein. But the sedimentation rate of modified plasma was in every case higher than that of normal ${ }^{2}$ plasma. The observed effects of adding or removing globulins must therefore be related to the presence or absence of these particular proteins, and not merely to changes in the relative amounts of total protein and salt. Typical experiments are presented in Table III.

2 The variability of the readings recorded for unmodified normal plasma is due to variations in the density of different lots of cell suspensions used for the tests. The sedimentation rates of all normal blood samples used, as determined by the Westergren technique, were less than $20 \mathrm{~mm}$. in 1 hour. 
TABLE III

The effect on the sedimentation rate of modifying normal plasma by the addition of various protein fractions from normal and rheumatic blood

Experiment 1

Normal plasma ......................... 55

Normal plasma plus fibrinogen and globulin from an equal volume of normal plasma $\ldots \ldots \ldots \ldots . .95$

Experiment 2

Normal plasma $\ldots \ldots \ldots \ldots \ldots \ldots \ldots \ldots \ldots \ldots . .35$

Normal plasma plus fibrinogen from equal volume of rheumatic plasma .....................

Experiment 3

Normal plasma $\ldots \ldots \ldots \ldots \ldots \ldots \ldots \ldots \ldots \ldots \ldots$ Normal plasma plus fibrinogen from rheumatic

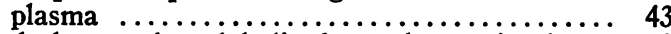

Normal plasma plus giobulin from rheumatic plasma 30

Experiment 4

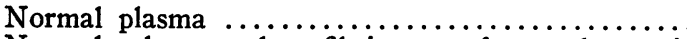

Normal plasma plus fibrinogen from rheumatic plasma ........................... 60

Normal plasma plus globulin from rheumatic plasma 12

Plasma from rheumatic patient ................. 140

Fibrinogen was definitely more effective than globulin in every case studied; nevertheless the globulin fractions showed considerable activity. However, the sedimentation rates of modified normal plasmas were in no case as high as those of the rheumatic plasmas from which the various fractions had been prepared. This may be attributed to partial denaturation, especially of fibrinogen, incident to precipitation, dialysis and other handling. In this connection, it may be of interest to note that the activity of serum separated from clotted blood was slightly higher than that of serum obtained by defibrination.

Similar experiments have been reported by Zárday and Farkas (21), who modified normal whole blood by the addition of graded amounts of normal fibrinogen, globulin and albumin. They found that the sedimentation rate was increased in proportion to the amount of fibrinogen and globulin added. Extra albumin, in contrast, reduced the rate. Our findings in acute rheumatism are entirely in accord with those of Zárday and Farkas for normal blood. It is therefore concluded that the interpretation of Fåhraeus (14), that changes in sedimentation rate depend on changes in the fibrinogen and globulin fractions of plasma, is applicable to acute rheumatism.

The mechanism whereby these proteins accelerate sedimentation is a matter of much contro- versy, and need not concern us here. A full discussion of the subject with complete bibliography is to be found in a recent monograph by Reichel (22).

\section{Immunological studies on fibrinogen and globulin} from rheumatic patients

The experiments just described indicated quantitative differences between the major protein fractions of normal (slowly sedimenting) and rheumatic (rapidly sedimenting) bloods. They did not show whether there might be qualitative differences. In order to investigate this point, an experiment was set up to detect immunological specificity of fibrinogen and globulin in rheumatic versus normal individuals, by means of precipitin tests with antisera to these proteins before and after absorption with homologous and heterologous protein fractions.

Fibrinogen and globulin fractions were obtained from the plasma of two classes of subjects: (1) Patients with acute rheumatism, with sedimentation rates of more than $100 \mathrm{~mm}$. in 1 hour; and (2) normal, healthy individuals with normal sedimentation rates. The protein solutions were all adjusted to contain equal concentrations of nitrogen. A portion of each sample was used for immunizing two rabbits, the remainder was kept sterile in the ice box. Strong precipitating antisera were obtained after four weeks of immunization. These antisera were divided into three parts. One part was stored untreated. One part was absorbed with its homologous antigen. The third part was absorbed with the corresponding protein fraction from the other class of subject. Absorptions were performed at $37^{\circ} \mathrm{C}$. After centrifugation, precipitin tests were set up with the supernatant serum.

These tests showed no distinction between normal and rheumatic fibrinogen or between normal and rheumatic globulin. It was not possible to absorb the antiserum to a fraction from a rheumatic patient with its normal equivalent and obtain a supernatant fluid which would give a precipitin reaction only with the homologous antigen. If absorption was complete, the serum could no longer be precipitated by either type. If incomplete, the serum could be precipitated equally well by protein from both normal and rheumatic individuals. Sample protocols are presented in 
TABLE IV

Precipitin reactions between plasma protein fractions and their antisera, before and after absorption*

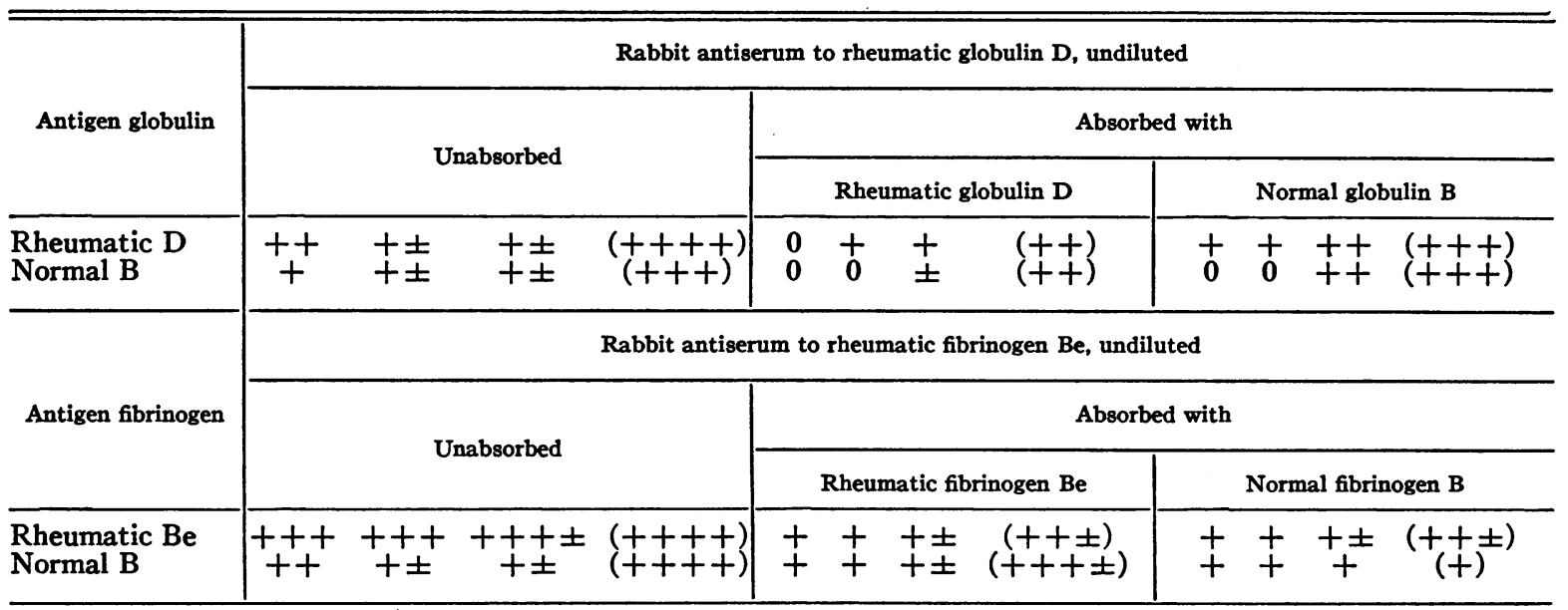

* Four readings are given for each test: (1) after 20 minutes at room temperature; (2) after 2 hours' incubation at $37.5^{\circ} \mathrm{C}$.; (3) after 18 hours in the refrigerator; (4) after centrifugation.

Table IV. A qualitative change in the fibrinogen and globulin fractions of the blood in acute rheumatism was not demonstrable by this method. The possibility of detecting such a change by more refined procedures remains open.

\section{DISCUSSION}

Having explained the high sedimentation rates of acute rheumatism as the result of increased plasma fibrinogen and globulin, our next problem is to account for the change in the proteins. At this point direct evidence comes to an end, and we can only look to the work of other investigators for possible analogies.

There is some evidence to indicate that fibrinogen and globulin are produced by the reticuloendothelial system. For example, sharp, transient increases in fibrinogen occur within two hours after the injection of substances which are taken up by reticulo-endothelium, according to Held and Behr (23), whereas "blocking" of the reticuloendothelial system by the previous injection of colloidal copper prevents this response. From these and other experiments it seems that an increase of fibrinogen may be a direct response of reticulo-endothelial cells to stimulation.

Increases in sedimentation rate during and following hemolytic streptococcus respiratory infections occur under three different clinical conditions. First, during the initial infection there may be a mild rise in sedimentation rate which probably represents the response of reticulo-endothelium to foreign substances in general. Second, during septic complications there is a further increase in sedimentation rate which may occur. in response to further invasion of the host by the infectious agent. The third condition is fulfilled by sterile inflammatory processes such as acute rheumatism, the onset of which is accompanied by a steep rise in the sedimentation rate curve to a high level. The intensity of this response suggests that a mechanism may be involved which differs from that in the first two conditions.

A number of observations have been made by independent authors which may apply to the development of the high sedimentation rate in acute rheumatism. One of these is Berger's (24) finding, that the second of two equal injections of foreign protein is followed by a much larger increase in serum globulin than the first, when the second dose is given after the complete subsidence of the globulin response to the first. The globulin curve following widely separated injections of foreign protein is similar to the sedimentation rate curve of pharyngitis followed by acute rheumatism.

Another possible analogy which presents itself is the development of high sedimentation rates by tuberculin-sensitive patients (15) or tuberculous rabbits (25) in response to injections of old tu- 
berculin. In these instances, as in rheumatism, the inflammatory process appears to be sterile and the sedimentation rate rises rapidly to high levels. Normal controls show no rise in sedimentation rate when similarly injected. Roch (26) has recently described a similar response following repeated injections of swine serum into rabbits. In his series, increases of sedimentation rate were largely confined to skin-sensitive animals (Arthus phenomenon).

The above findings all indicate that sharp increases of sedimentation rate can be expected in response to repeated doses of foreign protein. The rheumatic subject necessarily receives a dose of foreign protein during acute pharyngitis. A second dose of the same foreign protein received at the end of Phase II would account for the observed increase in sedimentation rate at that time. Whether there is a second dose, and if so, the nature of the protein involved, remain to be established.

\section{SUM M ARY}

In acute rheumatism, the sedimentation rate may be considered as a measure of the extent of inflammation.

The increased sedimentation rate in acute rheumatism is caused by an increase in plasma fibrinogen and globulin.

An immunological test for a qualitative difference between the plasma protein fractions of normal and rheumatic individuals gave negative results.

A possible type of mechanism is suggested to account for the rise in sedimentation rate just before the onset of a rheumatic attack.

The authors are indebted to Dr. A. B. Gutman and Ethel B. Gutman for a number of estimations of serum protein.

\section{BIBLIOGRAPHY}

1. Westergren, A., On the clinical import of the red cell sedimentation reaction in diseases of the joints. Acta med. Scandinav., 1926, Supp. 16, 343.

2. Kahlmeter, G., Uber die Bedeutung der Fåhreusschen Senkungsreaktion bei akuten und chronischen Arthritiden. Klin. Wchnschr., 1926, 5, 889.
3. Ernstene, A. C., Erythrocyte sedimentation, plasma fibrinogen and leucocytosis as indices of rheumatic infection. Am. J. M. Sc., 1930, 180, 12.

4. Hill, N. G., The erythrocyte sedimentation rate in juvenile rheumatism. Brit. J. Child. Dis., 1932, 29, 181.

5. Payne, W. W., Acute rheumatism and the sedimentation rate. Lancet, 1932, 1, 74.

6. Struthers, R. R., and Bacal, H. L., Determination of the activity of rheumatic infection in childhood. Canad. M. A. J., 1933, 29, 470.

7. Struthers, R. R., and Bacal, H. L., The relationship of the sedimentation rate in rheumatic infection in childhood to alteration in the albumin-globulin ratio. Canad. M. A. J., 1934, 31, 603.

8. Perry, C. B., The sedimentation rate in rheumatic carditis. Arch. Dis. Childhood, 1934, 9, 285.

9. Elghammer, H. W., Erythrocyte sedimentation rate in rheumatic infection. Arch. Pediat., 1934, 51, 281.

10. Payne, W. W., and Schesinger, B., A study of the sedimentation rate in juvenile rheumatism. Arch. Dis. Childhood, 1935, 10, 403.

11. Wood, Paul, The erythrocyte sedimentation rate in diseases of the heart. Quart. J. Med., 1936, 5, n. s., 1.

12. Coburn, A. F., and Pauli, R. H., Studies on the immune response of the rheumatic subject and its relationship to activity of the rheumatic process. Observations on the reactions of a rheumatic group to an epidemic infection with hemolytic streptococcus of a single type. J. Exper. Med., 1935, 62, 159.

13. Rhodin, $\mathrm{H}$., La réaction de sédimentation du sang dans la fièvre scarlatine. Acta med. Scandinav., 1926, Supp. 16, 336.

14. Fåhraeus, R., The suspension stability of the blood. Physiol. Rev., 1929, 9, 241.

15. Westergren, A., Theorell, H., and Widström, G., Plasmaeiweiss, Blutlipoide, Erythrocyten und Senkungsreaktion. Ztschr. f. d. ges. exper. Med., 1931, 75, 668.

16. Bendien, W. M., and Snapper, I., Zusammenhang zwischen der Senkungsgeschwindigkeit der roten Blutkörperchen und dem Eiweissspektrum. Biochem. Ztschr., 1931, 235, 14.

17. Gilligan, D. R., and Ernstene, A. C., The relationship between the erythrocyte sedimentation rate and the fibrinogen content of plasma. Am. J. M. Sc., 1934, $187,552$.

18. Hartley, P., Observations on the rôle of the ethersoluble constituents of serum in certain serological reactions. Brit. J. Exper. Path., 1925, 6, 180.

19. Theorell, H., Studien über die Plasmalipoide des Blutes. Biochem. Ztschr., 1930, 223, 1.

20. Ohlson, B., and Rundquist, O., Uber die Bedeutung der Plasmalipoide für die Suspensionsstabilität des Blutes. Biochem. Ztschr., 1932, 247, 249.

21. Zárday, I., and Farkas, G., Quantitative Beziehungen 
zwischen Plasmaeiweissfraktionen und Blutsenkung. Ztschr. f. d. ges. exper. Med., 1931, 78, 367.

22. Reichel, $H$., Blutkörperchensenkung. Julius Springer, Wien, 1936.

23. Held, A., and Behr, C. H., Die Rolle des Reticuloendothels bei der Bildung des Fibrinogens. Klin. Wchnschr., 1934, 13, 1120.

24. Berger, W., Über die Hyperproteinämie nach Eiweissinjektionen. Ein experimenteller Beitrag zur
Pathologie des Serumproteins und zur Proteinkörpertherapie. Ztschr. f. d. ges. exper. Med., 1922, 28, 1.

25. Freund, J., and Frank, D. E., The sedimentation rate of red blood cells of tuberculous rabbits injected with tuberculin. J. Immunol., 1933, 24, 247.

26. Roch, Hans, Utber die Blutkörperchensenkungsreaktion des sensibilisierten Versuchstieres. Virchow's Arch. f. path. Anat., 1935, 295, 399. 